\title{
New Data on the Mineralogy of Chromite from the Nuggihalli Schist Belt, Western Dharwar Craton, Karnataka, India: Petrogenetic Implications
}

\author{
P.V.S RAJU ${ }^{1, *}$ E.V.S.S.K BABU ${ }^{1}$ and R.K.W MERKLE ${ }^{2}$ \\ 1 National Geophysical Research Institute, Hyderabad, India (Council of Scientific and Industrial Research) \\ 2 Department of Geology, University of Pretoria, Pretoria, South Africa \\ * Corresponding author. E-mail: perumala.raju@gmail.com
}

\begin{abstract}
The occurrence of rhythmic layering of chromite and host serpentinites in the deformed layered igneous complexes has been noticed in the Nuggihalli schist belt (NSB) in the western Dharwar craton, Karnataka, South India. For this study, the chromitite rock samples were collected from Jambur, Tagadur, Bhakatarhalli, Ranganbetta and Byrapur in the NSB. Petrography and ore microscopic studies on chromite show intense cataclasis and alteration to ferritchromite. The ferritchromite compositions are characterized by higher $\mathrm{Cr}$ number $(\mathrm{Cr} /[\mathrm{Cr}+\mathrm{Al}])(0.68-0.98)$ and lower $\mathrm{Mg}$ number $(\mathrm{Mg} /[\mathrm{Mg}+\mathrm{Fe}])(\mathbf{0 . 3 3}-\mathbf{0 . 8 2})$ ratios in ferritchromite compared to that of parent chromite. The formation process for the ferritchromite is thought to be related to the exchange of $\mathrm{Mg}$, $\mathrm{Al}, \mathrm{Cr}$, and $\mathrm{Fe}$ between the chromite, surrounding silicates (serpentines, chlorites), and fluid during serpentinization.
\end{abstract}

Key words: chromite, ferritchromite, Nuggihalli schist belt, Dharwar craton, India

\section{Introduction}

Chrome-rich spinels and $\mathrm{Fe}$ - Ti oxides are ubiquitous accessory phases in mafic-ultramafic igneous rocks, and in certain instances, they can concentrate as ore bodies (Cameron et al., 1959; 1969). Most of the stratified chromitite deposits occur in stable cratonic areas and are characterized by lateral persistence and depth extent. The origin of chromitite is still a debatable issue (Vermaak, 1986). Understanding the chromerich spinels also helps in deciphering the ore forming processes (Alapieti et al., 1989). The chromite chemistry commonly shows a significant solid solution and is very sensitive to record changes in magmatic parameters, so that the chemistry and textural variations of chromite are useful indicators of crystallization (Roeder \& Campbell, 1985). The chrome ores are composed largely of Cr-rich spinels that display marked compositional variation between different deposits (Irvine, 1965; 1967; Roeder et al., 1979; Barnes and Roeder., 2001). The phase relationships in these oxide systems are complicated by the effects of an extensive solid solution at elevated temperatures, and the influence of intrinsic characteristics of the silicate melt (i.e. bulk composition, oxygen fugacity), as well as the effects of subsolidus re-equilibration between co-existing phases (Murck \& Campbell, 1986; Irvine, 1967). Chrome spinels are also tested for the validity of provenance and as a petrogenetic indicator (Power et al., 2000).

The textural and compositional variations in chromitite play a vital role in understanding the primary magmatic compositions, as it represents early crystallization phases (Irvine, 1967). An understanding of the spinel crystal chemistry, phase relationship, and behavior during fractional crystallization is important (Irvine, 1967; 1975). In a global context, the economic grades of chromite mineralization are constrained to a time interval of 2900-2000 Ma, and coincide with the peak in continental growth rates (Stowe, 1994). In contrast, few high-grade chromite deposits have been discovered in China during the Early Paleozoic (Qilian Qinling belt), late Paleozoic (Jinsha-Ailao, Kunlun, Tianshan, Junggar, Inner Mongolia, and Nadanhada belts), and Mesozoic (Yarlungzanbo and Bongong-Nunjiang belts) (Zhou \& Bai, 1992). The $\mathrm{Cr} / \mathrm{Fe}$ ratio (a 
significant parameter in the economics of chromite) might decline with younger age, perhaps indicating that the younger mafic intrusions originate from Cr-depleted magmas (Stowe, 1994).

In the present paper, we describe the mineralogy of chromite from the Archean Nuggihalli schist belt (NSB), Western Dharwar Craton, South India, and discuss its characteristic ferritchromite composition with petrogenetic implications.

\section{Geology of the Area}

The Dharwar Craton of South India is one of the major Archean crustal blocks with lithological units as old as $3.6 \mathrm{Ga}$. It is limited to the north-northeast by the Narmada-Son-Godavari rift system, to the west by the western margin of the subcontinent, towards the east by the Eastern Ghats mobile belt, and towards the south it is separated by granulite terrain by the transition zone (Fig. 1). The craton is divided into two tectonic blocks (after Swaminath et al., 1976): the western block and the eastern block, renamed respectively as the western Dharwar craton (WDC) and the eastern Dharwar Craton (EDC) by Rogers (1986). The WDC and EDC are separated by the Chitradurga shear zone that is situated at the eastern margin of the Chitradurga schist belt near to the western margin of Closepet granite. The region west of Closepet granite is designated as WDC and that to the east, the EDC. The WDC is predominantly made up of greenstone belts and tonalitetrondjhemite gneisses (TTG) with granites. The EDC predominantly consists of varied types of granitods and auriferous greenstone belts (Raju., 2009 and Raju et al., 2006). In the WDC, the Mesoarchaean rocks are found in Holenarsipur nuclei and its adjacent areas in the NSB. The oldest rock types in the Dharwar craton were named as the Sargur group, with the Holenarsipur group and older supracrustals. The rock types present in the Holenarsipur schist belt are mainly mafic-ultramafic schists \pm anorthosites, meta-sediments, TTG, and para-gneisses. The ultramafic schists consist of spinifex-textured peridotitic komatiites, as reported by Hussain and Naqvi (1982). The NSB (Fig. 1) is a linear, ultramafic body running centrally within a major mafic-ultramafic zone of the WDC. The Nuggihalli belt extends for nearly $\sim 50 \mathrm{~km}$ (north-northwest trend) from Kempinkote in the south to Arsikere in the north and varies from 1 to $3 \mathrm{~km}$ in width, with the maximum width at the central part of the Nuggihall (Jafri et al,1983). The rock type includes chromitebearing serpentinized peridotite, talc-tremolitechlorite schists, amphibolites metasediments (fuchsite quartzite, quartz-mica chlorite schist, and staurolitequartz-mica schist) (Ramakrishnan, 1981). The chromitite mineralization usually occurs as lenses, tabular or irregular bodies in the NSB. The chromite deposits are reported from the Jambur, Tagadur, Bhakatarhalli, Ranganbetta and Byrapur areas (Radhakrishna, 1957) (Fig. 1B). The chromitite samples for this study were collected from the same areas. The ultramafic bodies with chromite-bearing anorthosites are deformed and mostly occur in the gneisses. A similar type of geological set-up was reported to be found in the Messina layered intrusion in the Limpopo belt of South Africa (Barton et al., 1979) and the Fiskenaesset complex in west Greenland (Windely et al., 1973).The largest chromitite reef is found in the Byrapur chromite mine (Nijagunappa \& Naganna, 1983). To date, the evidence on the age for these ultrabasic bodies is lacking, except for an estimated age of $>3.0 \mathrm{Ga}$ (Baidyananda et al., 2003) for the metasediments of the NSB. Earlier workers carried out studies on samples from individual chromitite mines with very scanty data (Sahu \& Nair, 1982; Baidyananda \& Mitra, 2005). The ultramafic mafic complexes regionally extend from the Kadakola magnesite mines, Tallur and Sinduvalli, which are old chromite mines in the south, to Kadur, Shivani and Davangari in the north, over a total strike length of more than $400 \mathrm{~km}$, suggesting a similarity with the Great Dyke in Zimbabwe (Radhakrishna, 1957). Chromite-bearing ultramafic rocks are found along the axial region of the anticlinorium. Within the ultramafic complexes, there are no recognizable hornblendic rocks that can be correlated with the basic traps of the lower Dharwar. The ultramafic rocks are older than the gneisses and have undergone metamorphic overprinting. Radhakrishna (1957) described the order of sequence of the rocks in the Byrapur chromite mines in the NSB. The lithological units consist of dunite, pyroxenite, and chromite ore bodies confined to the base of the serpentinized peridotite. In the Byrapur mines, two distinct periods of serpentinization with chromite are reported by Radhakrishna (1957). The main ore lenses were displaced to their present position after the consolidation of the ultramafics and the opening up of fissures (Radhakrishna, 1957). Aeromagnetic surveys by the Airborne Mineral Survey Exploration wing of the Geological Survey of India, in collaboration with the Bureau de Recherches Géologiques et Minières of France, have enabled the delineation of a gossan zone near Aladahalli. The gossan indicates sulfide 
mineralization with high copper content, which warrant further detailed studies. The field investigations in the aerial electromagnetic anomaly zones have revealed the presence of north-northeast-trending enclaves of pelitic schists containing garnet, staurolite, and kyanite, together with associated cordierite anthophyllite rocks, ultramafics, anorthosites, and amphibolites. These rocks constitute the Aladahalli band, which forms an arm of the Nuggihalli belt extending from Byrapur to Ugrahalli, and could host $\mathrm{Cu}-\mathrm{Ni}$ mineralization (Subba Rao \& Naqvi, 1997).

\section{Analytical Procedures}

Chromite grains from different samples were analyzed using four wavelength-dispersive spectrometers on a Cameca SX-100 electron microprobe facility (Cameca, France) at the National Geophysical Research Institute, Hyderabad, India. The element peak and background positions were carefully chosen to avoid peak interferences. In cases of unavoidable interferences, Cameca internal-overlap correction procedures were applied. An acceleration voltage of $20 \mathrm{kV}$ and a beam current of $20 \mathrm{nA}$ were applied throughout all analyses. Counting times were adjusted so that the net-count rates for all elements were within 3 sigma errors of the lower level-detection element requirements. Before the automated runs, mineral standards were analyzed as unknown, and recalibrations were made when necessary. With the completion of automated runs, the data were checked and mineral grains with suspect results were re-analyzed or tested with wave length dispersive spectrometer scans for possible missing elements. Pictures of ferritchromite were taken in back-scattered electron image mode for guiding the chemical analysis.

\section{Petrography of Chromites}

More than 450 electron microprobe analyses were performed on chromite crystals $(n=50)$ from polished sections $(n=50)$ of the chromitite samples. The chromite grains were generally euhedral-to-subhedral with sizes up to $50 \mu \mathrm{m}$ with $(>90)$ modals of the percentage of chromite in a silicate matrix, predominantly comprising orthopyroxene, minor olivine altered to serpentine, calcite, magnesite, talc variants and minor amounts of ilmenite, and magnetite. The typical variant of magnetite present are ilmenomagnetites. The chromite grain color varied from dark brown to red in thin section. The chromite grains in some polished sections showed extensive cataclasis. The presence of silicate inclusion of $<0.2-5 \mu \mathrm{m}$ is common; in particular, the metamorphic overprinting in the form of rounded rims within the chromite grains were still preserved in the primitive chromite grains. A chromian clinochlore variety, Kaemmererite, was present in association with ferritchromite.

\section{Results}

\subsection{Normal chromite}

By microprobe technique, a vertical profile length of 50 points (Fig. 2A, B) cross the normal chromite grain was carried out. There was a steep increase in the $\mathrm{Cr}_{2} \mathrm{O}_{3}$ composition at the rims (average $\sim 44 \mathrm{wt} \%$ ) and decrease in the core (average $42 \mathrm{wt} \%$ ). At the 25 th point from the core, the decrease in the chromite composition varied between $8 \%$ and $18 \%$, and there is a relative concomitant increase in $\mathrm{SiO}_{2}(\sim 27 \mathrm{wt} \%)$, $\mathrm{Al}_{2} \mathrm{O}_{3}(\sim 18 \%), \mathrm{FeO}(\sim 10 \mathrm{wt} \%)$, and $\mathrm{MgO}(\sim 30 \mathrm{wt} \%)$. The increase in the $\mathrm{MgO}$ composition was up to 30 $\mathrm{wt} \%$. This could be due to the minor Mg-rich inclusions within the chromite grain. From points 5-18, a steep increase in $\mathrm{Al}_{2} \mathrm{O}_{3}(\sim 12.55 \mathrm{wt} \%)$ was observed. The enrichment of $\mathrm{Fe}$ was also concomitant with $\mathrm{Cr}$ content.

\subsection{Ferritchromite}

In Figure 4, a vertical profile from points 1 to 14, and a horizontal profile from 15 to 32 was carried out on the ferritchromite grain. At the rims, the marked decrease of $\mathrm{Fe}, \mathrm{Cr}$, and $\mathrm{Al}$ was observed, and an increase in the core from points 17 to 28 . The $\mathrm{Cr}$ content reached up to $\sim 48 \mathrm{wt} \%$, and this decrease in $\mathrm{Cr}, \mathrm{Al}$, and $\mathrm{Fe}$ could reflect the parent chromite composition. The elements like $\mathrm{Mg}$ and $\mathrm{Fe}$ are strongly zoned in the parent chromite and with low levels of $\mathrm{Mg}$ and high levels of Fe near the edge of ferritchromite. The representative chromite analysis is plotted in the binary diagrams: $\mathrm{Cr}$ number versus $\mathrm{Mg}$ number (Fig. $3 \mathrm{~A}$ ), $\mathrm{Al}_{2} \mathrm{O}_{3}$ versus $\mathrm{TiO}_{2}$, (Fig. 3B), $\mathrm{Al}_{2} \mathrm{O}_{3}$ versus $\mathrm{MgO}$ (Fig. $3 \mathrm{C}$ ), and $\mathrm{Al}_{2} \mathrm{O}_{3}$ versus $\mathrm{Fe}_{2} \mathrm{O}_{3}$ (Fig. 3D). The profile cut across a few 
$\sim 5 \mu \mathrm{m}$-size Mg-rich inclusions. In the profile, the chromium $\mathrm{Cr}$ and magnesium $\mathrm{Mg}$ number ratios varied between 0.68 and 0.98 and 0.33 and 0.82 , respectively. At the core portions, an increase in the Fe content in the ferritchromite area was observed in comparison with the parent chromites (Fig. 5). The partial replacement of original chromite with the inner rim of the slightly darker zone of chromian magnetite is also present. The adjacent grains contain minor inclusions that could represent the original parent chromite boundary. The chromite cores completely disappeared in the adjacent grains. The grain boundaries in the partly-altered chromites showed up well in reflected, as well as back-scattered, light. The zones had a rounded shape, which was completely different from the other chromite grains. This represents a compositional variation of the different textural types of chromite to show an influence of metamorphic overprinting (the chromite in the triangle), which is thought to be of parent chromite composition. In summary, the binary diagrams show that during change in the original chromite composition to ferritchromite, there is a decrease in $\mathrm{Mg}$ and $\mathrm{Al}$, an increase in $\mathrm{Ti}$ and $\mathrm{Fe}$, and a redistribution of $\mathrm{Cr}$. The later mechanism could increase the $\mathrm{Cr}$ number and could have resulted in the formation of ferritchromite. From the back scattered electron (BSE) images, the observations revealed that there was a distinct boundary between the parent chromite-ferritchromite contacts. Data are shown in Table 1 for ferritchromite profile only.

\subsection{Fe, $\mathrm{Cr}$, and $\mathrm{Al}$ element maps}

Individual mineral maps of $\mathrm{Fe}, \mathrm{Cr}, \mathrm{Al}$, and $\mathrm{Mg}$ were developed (Fig. 6) using mineral mapping software by EPMA-SX-100 (CAMECA, France). The core had a composition of ferrian chromite, with distinctly higher $\mathrm{MgO}$ and $\mathrm{Al}_{2} \mathrm{O}_{3}$, whereas the rims represented enriched original chromite composition. i.e., parent chromite. At the rims, there was a marginal decrease in $\mathrm{Cr}_{2} \mathrm{O}_{3}$ and $\mathrm{FeO}$ contents.

\section{Discussion}

The formation of ferritchromite constitutes either the formation of an Fe-enriched rim in primary chromite grains due to cation exchange, or to an overgrowth of a more Fe-rich zone on the primary chromite, or a combination of these two processes. The availability of iron is due to the formation of secondary minerals from the rock forming silicates, which prefer to incorporate $\mathrm{Mg}$ and release Fe to the fluid phase. Iron prefers to partition into the spinel structure which causes the formation of ferritchromite. The presence of ferritchromite is an indication of fluid activity in the rock, typically during the cooling stage of igneous rocks, or during retrograde hydration in metamorphic terrains. The composition of ferritchromite (and the relationships between the main components of ferritchromite) will vary depending on the primary composition of the chromite, the alteration reactions of the silicate matrix (which controls the composition of circulating fluids), and the temperature at which the alteration takes place. Variations in the exact mechanism of ferritchromite formation must be expected for different host rocks.

In rocks that suffered multiple overprinting, ferritchromite will in all likelihood represent the youngest event. It is not uncommon to find variable degrees of ferritchromite formation even on the scale of a single polished section, depending on the silicate mineralogy, grain sizes, and textures, which can strongly influence the accessibility of fluids to individual chromite grains.

The primary chromite in the investigated rocks appears to be unusually low in magnesium and rather rich in iron. Whether this is a primary (i.e., magmatic) feature of the chromite or the result of a high grade metamorphic homogenization of an earlier overprinting can at present not be answered and requires further studies.

If ferritchromite formation would only be due to the addition of iron (i.e., the "dilution" of the original chromite composition by iron), then the ratios of the original components of chromite ( $\mathrm{Mg}, \mathrm{Al}, \mathrm{Cr}$ ) should remain constant across chromite grains and their ferritchromite rims. However, graphical presentation of $\mathrm{MgO}-\mathrm{Al}_{2} \mathrm{O}_{3}$ and $\mathrm{Cr}_{2} \mathrm{O}_{3}-\mathrm{Al}_{2} \mathrm{O}_{3}$ clearly show differences between core, rim, and the transition zone.

From the relationships of the most important components of the original chromite and ferritchromite, it can be deduced that during ferritchromite formation, the small amount of $\mathrm{MgO}$ present in the cores of the chromite was substituted for by $\mathrm{FeO}$. It appears that aluminium was replaced first by $\mathrm{Fe}^{+}$, followed by the dominant replacement (or dilution) of chromium by $\mathrm{Fe}^{+}$. In the process, titanium was enriched in the rims together with $\mathrm{Fe}^{+}$, but the lack of a clearly defined relationship between the two elements implies a more 
complex substitution reaction. Comparison of the relationships of $\mathrm{Ti}$ with $\mathrm{Fe}^{+}$, aluminium, and chromium implies that aluminium again was preferentially replaced (leading to a smooth relationship between Ti- and Al-concentrations), followed by the substitution of titanium for chromium.

\title{
7 Conclusions
}

Detailed microprobe analyses of ferritchromite from Nuggihalli schist belt confirms the generally known fact that original chromite is rimmed by zones of higher Fe-content. We can demonstrate that the composition of the ferritchromite is not only an effect of dilution of the original chromite composition, but also the effect of substitution of original components of the chromite by iron. It is clear that magnesium and aluminium get preferentially removed from the chromite and substituted by iron of both oxidation stages.

\section{Acknowledgements}

These research results are part of an ongoing DST project by PVSR (no. GAP 538-28 [PVSR]), funded by the Department of Science and Technology, Government of India. The authors are grateful to Dr Y.J.Bhaskar Rao, Acting Director, National Geophysical Research Institute, for his encouragement.

\begin{abstract}
About the first author
Dr Raju was born in India in 1970, and currently works as a senior scientist at the National Geophysical Research Institute (Council of Scientific and Industrial Research) India. He specializes in Precambrian geology (especially the Dharwar craton, Karnataka) and in understanding the mechanisms for hosting $\mathrm{Ni}-\mathrm{Cu}$ -Cr, gold and platinum group elements in different cratons. At present, he is the principal scientist for two projects funded by Department of Science and Technology, Govt of India, to understand the chromitite-PGE occurrences in the Dharwar craton. Dr Raju is an honorary member of many national and international societies and has authored over thirty five scientific publications and presented equal number of papers at national/international conferences.
\end{abstract}




\section{References}

Alapieti, T.T., Kujanpää, J., Lahtinen, J.J., and Papunen, H., 1989. The Kemi stratiform chromitite deposit, Northern Finland. Economic Geology, 84: 1057-1077.

Baidyananda, M., Deomurari, M.P., and Goswami, J.N., 2003. ${ }^{207} \mathrm{~Pb}-{ }^{206} \mathrm{~Pb}$ ages of Zircon from Nuggihalli schist belt, Dharwar craton, southern India. Current Science, 85: 1482-1485.

Baidyananda, M., and Mitra, S., 2005. Chromitites of komatiitic affinity from the Archean Nuggihalli greenstone belt in south India. Mineralogy and Petrology, 84: 169-187.

Barnes, S.J., and Roeder, P.L., 2001. The range of spinel compositions in terrestrial mafic and ultramafic rocks. Journal of Petrology, 42: 2279-2302.

Barnes. S.J., 2000. Chromite in komatiites, II. Modification during green schist to mid amphibolite facies metamorphism. Journal of Petrology, 41: 387-409.

Barton, J.M.Jr., Fripp, R.E.P., Horrocks, P., and Mc Lean, N., 1979. The geology, age and tectonic setting of the Messina Layered Intrusion, Limpopo mobile belt, southern Africa. American Journal of Science, 279: 1108-1134.

Cameron, E.N., and Desborough, G.A., 1969. Occurrence and characteristics of chromite deposits-Eastern Bushveld Complex. Economic Geology Monograph, 4: 23-40.

Cameron, E.N., and Emerson, M.E., 1959. Evolution of the lower critical zone, central sector, Eastern Bushveld Complex, and its chromite deposits. Economic Geology, 75: 845-871.

Christofides, G., Thimiatis, Koroneos A., Sklavounos, S., and Eleftheriadis, 1994. Mineralogy and chemistry of Cr-Chlorites associated with chromites from Vavdos and Vasilika Ophiolite Complexes (Chalkidiki, Macedonia, N Greece). Chemie der Erde, 54: 151-164.

Hussain, S.M., and Naqvi, S.M., 1982.Geochemistry and significance of mafic-ultramafic rocks from the southern part of Holenarsipur schist belt, Karnataka, Journal Geological Society of India, 32: 19-31.

Irvine, T.N., 1965. Chromian spinel as a petrogentic indicator, part 1, theory. Canadian Journal of Earth Science, 2: 648-671.

Irvine, T.N., 1967. Chromian spinel as a petrogentic indicator, part 2. Canadian Journal of Earth Science, 4:71-103.

Irvine, T.N., 1975.Crystallization sequences in the Muskox intrusion and other layered intrusions-II.Origin of chromite layers and similar deposits of other magmatic ores. Geochimica Cosmochimica Acta, 39: 9911020 .

Jafri, S.H., Khan, N., Ahmed, S.M., and Saxena, A.R., 1983. Geology and geochemistry of Nuggihalli schist belt, Dharwar craton, Karnataka, India. Memoir Geological Society of India, 12: 110-120.

Michailidis, K.M., 1995. Compositional variation of zoned chromian spinels in serpentinites from the Kilkis area, northern Greece. Chemie der Erde, 55: 81-96.

Mihalik, P., and Saager, R., 1968.Chromite grains showing altered borders from the Basal Reef, Witwatersrand System. American Mineralogist, 53: 1543-1550.

Murck, B.W., and Campbell, I.H., 1986. The effects of temperature, oxygen fugacity and melt composition on the behaviour of chromium in basic and ultrabasic melts. Geochim.Cosmochim. Acta, 50: 1871-1887.

Nijagunappa, R., and Naganna, C., 1983. Nuggihalli schist belt in the Karnataka craton: an Archean layered complex as interpreted from chromite distribution. Economic Geology, 78: 507-513.

Power, M.R., Pirrie, D., Andersen, J.C.Ø., and Wheeler, P.D, 2000. Testing the validity of chrome spinel chemistry as a provenance and petrogenetic indicator. Geology, 28: 1027-1030.

Radhakrishna, B.P., 1957. Mode of occurrence of chromite at Byrapur, Mysore state, India: Mysore, Geological Association of Mysore Bulletin, 12: 1-13.

Ramakrishnan, M., 1981. Nuggihalli and Krishnarajpet belts, Early Precambrian supracrustals of southern Karnataka: India edn, Early Precambrian Supracrustals of Southern Karnataka, Geol. Surv. India Memo. 112: 249-259.

Raju P.V.S, Charan S.N, Subba Rao D.V, Uday Raj.B and Naqvi S.M (2006), Nature of shear zone hosted epigenetic gold mineralisation in BIF of Chitradurga Schist Belt, Karnataka, Journal of the Geological Society of India, 68, 577-581.

Raju, P.V.S. (2009), Petrography and geochemical behaviour of trace element, REE and precious metal signatures in sulphidic banded iron formation of C.S.Halli , Chitradurga Schist Belt, Dharwar Craton, Journal of Asian Earth Sciences, 34, 663-673.

Rogers, J.J.W., 1986. Dharwar Craton and the assembly of Peninsular India. Journal of Geology.94: 129143.

Roeder, P.L., Campbell, I.H., and Jameison, H.E., 1979. A re-evaluation of the olivine-spinel geothermometer.Contributions Mineralogy and Petrology, 68: 325-334. 
Roeder, P.L., and Campbell, I.H., 1985. The effect of post cumulus reactions on composition of chromespinels

from the Jimberlana intrusion. Journal of Petrology 26:763-786

Subba Rao, D.V., and Naqvi, S.M., 1997. Geological setting, mineralogy, geochemistry and genesis of the Middle Archaean Kalyadi copper deposit, western Dharwar Craton, southern India. Mineralium Deposita, 32: $230-242$.

Sahu, K.C., and Nair, A.M., 1982.The chromites of Byrapur, Karnataka. Journal of the Geological Society of India, 23: 330-337.

Scowen, P.A.H., Roedder, P.L., and Heltz, R.T., 1991. Reequilibration of chromite within Kiliauea Iki lava lake, Hawaii, Contributions to Mineralogy and Petrology, 107: 1-12.

Stowe, C., 1994.Tectonic compositions and settings of chromite deposits through time. Economic Geology. 89: 528-546.

Swaminath, J., Ramakrishna, M., and Viswanatha, M.N., 1976. Dharwar stratigraphic model and Karnataka evolution. Records Geological Survey of India, 107: 149-175

Vermaak, C.F., 1986. Summary aspects of the economics of chromium with special reference to southern Africa. In: Anhaeusser, C.R., and Maske, S. (Eds.). Mineral Deposits of Southern Africa. Geological Society of South Africa, Johannesburg, 2: 1155-1181

Windely, B.F., 1973.Archaean anorthosites: A review with the Fiskenaesset Complex, west Greenland, as a model for interpretation. Geol. Soc. South Africa Spec. Pub, 3: 319-332.

Zhou Mei-Fu and Bai Wen-Ji 1992. Chromite deposits in China and their origin. Mineralium Deposita, 27: 192-199.

Fig 1 . Geological map of Dharwar Craton (after Naqvi et al., 1975) inset the study area shown in enlarge view and Geological map of Nuggihalli Schist Belt modified after (Jafri et al., 1983)

Fig 2 A. Backscattered image with a line profile of 50 points on Ferritchromite

Fig 2 B. A line profile is carried on the altered chromite. The profile reflects the enrichment of $\mathrm{Cr}$ at the rims and decrease in the core. The enrichment of $\mathrm{Fe}$ is also concomitant with $\mathrm{Cr}$ content. The profile cut across few inclusions of $\sim 5$ microns and inclusions are found to be enriched in high $\mathrm{Mg}$ contents which is reflected the graph

Fig 3. A Binary diagram of $\mathrm{Cr} \# \mathrm{Vs} \mathrm{Mg \#}$

Fig 3 B, C, D The representative chromite analysis is plotted in the binary diagrams which represent a compositional variations of the different textural types of chromite to show an influence of metamorphic overprinting ( the chromite in triangle) is thought to be of parent chromite composition

Fig. 3.C Binary diagram of $\mathrm{Al}_{2} \mathrm{O}_{3}$ vs $\mathrm{MgO}$

Fig. 3.D Binary diagram of $\mathrm{Al}_{2} \mathrm{O}_{3}$ vs $\mathrm{Fe}_{2} \mathrm{O}_{3}$

Fig 4. X-Y profile in ferritchromite showing element variation from rim to core (note: $\mathrm{x}$ axis -distance in microns; Y axis - Counts/Sec)

Fig 5.Complete replacement, inner slightly darker zone of chromian magnetite. Also contain few inclusions making original chromite boundary. Chromite cores are completely disappeared (parent chromite)

Fig .6 . (a) Element map of Fe enrichment in ferritchromite (b) Element map of $\mathrm{Cr}$ enrichment in ferritchromite (c) Element map of $\mathrm{Al}$ enrichment in ferritchromite (d) Element map of $\mathrm{Mg}$ enrichment in ferritchromite 


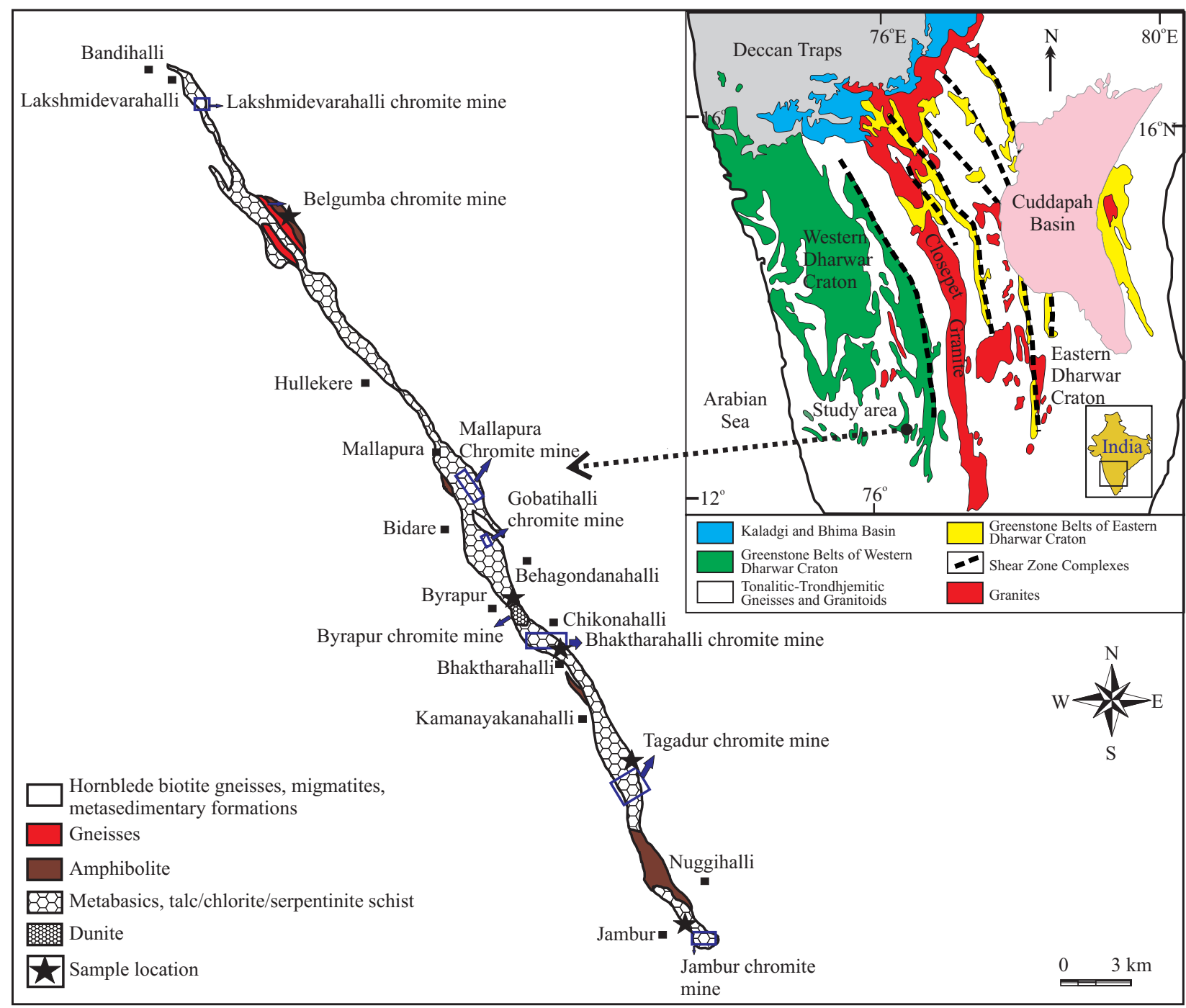

Fig. 1. Geological map of Dharwar Craton (after Naqvi et al., 1975) inset the study area shown in enlarge view and geological map of Nuggihalli Schist Belt modified after (Jafri et al., 1983).
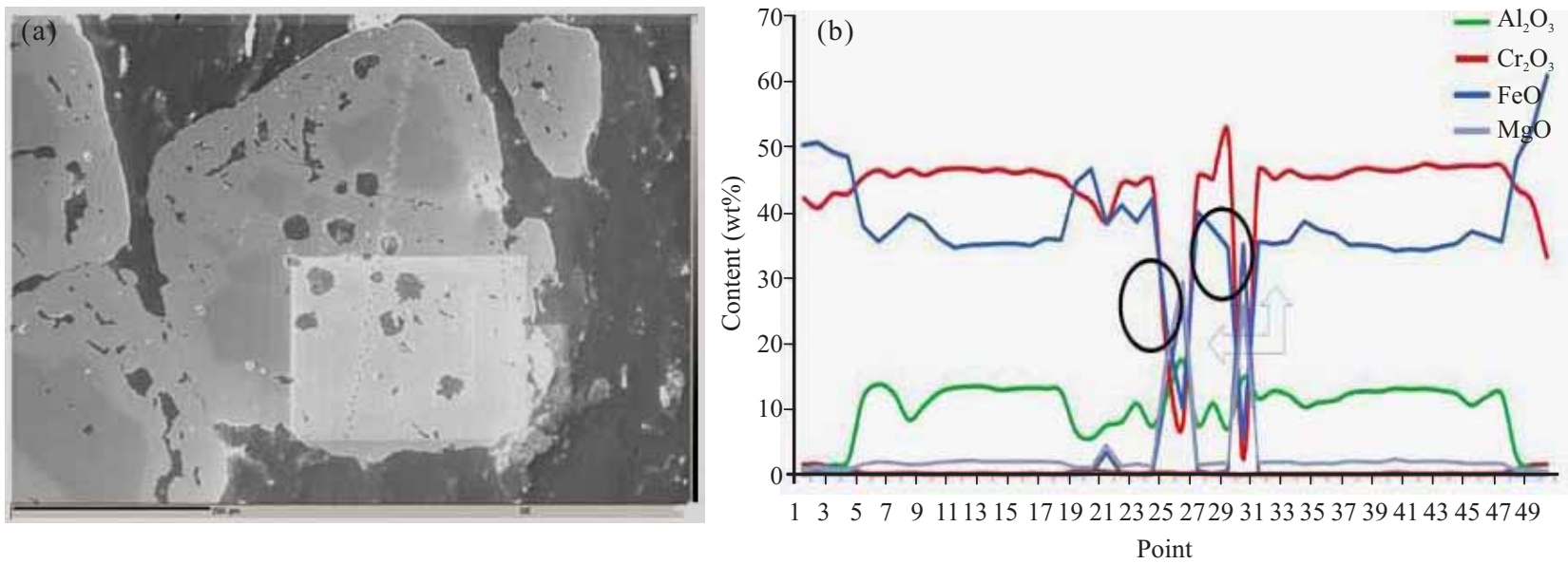

Fig. 2. (a), backscattered image with a line profile of 50 points on ferritchromite; (b), a line profile is carried on the altered chromite. The profile reflects the enrichment of $\mathrm{Cr}$ at the rims and decrease in the core. The enrichment of Fe is also concomitant with $\mathrm{Cr}$ content. The profile cut across few inclusions of $\sim 5$ microns and inclusions are found to be enriched in high $\mathrm{Mg}$ contents which is reflected the graph. 

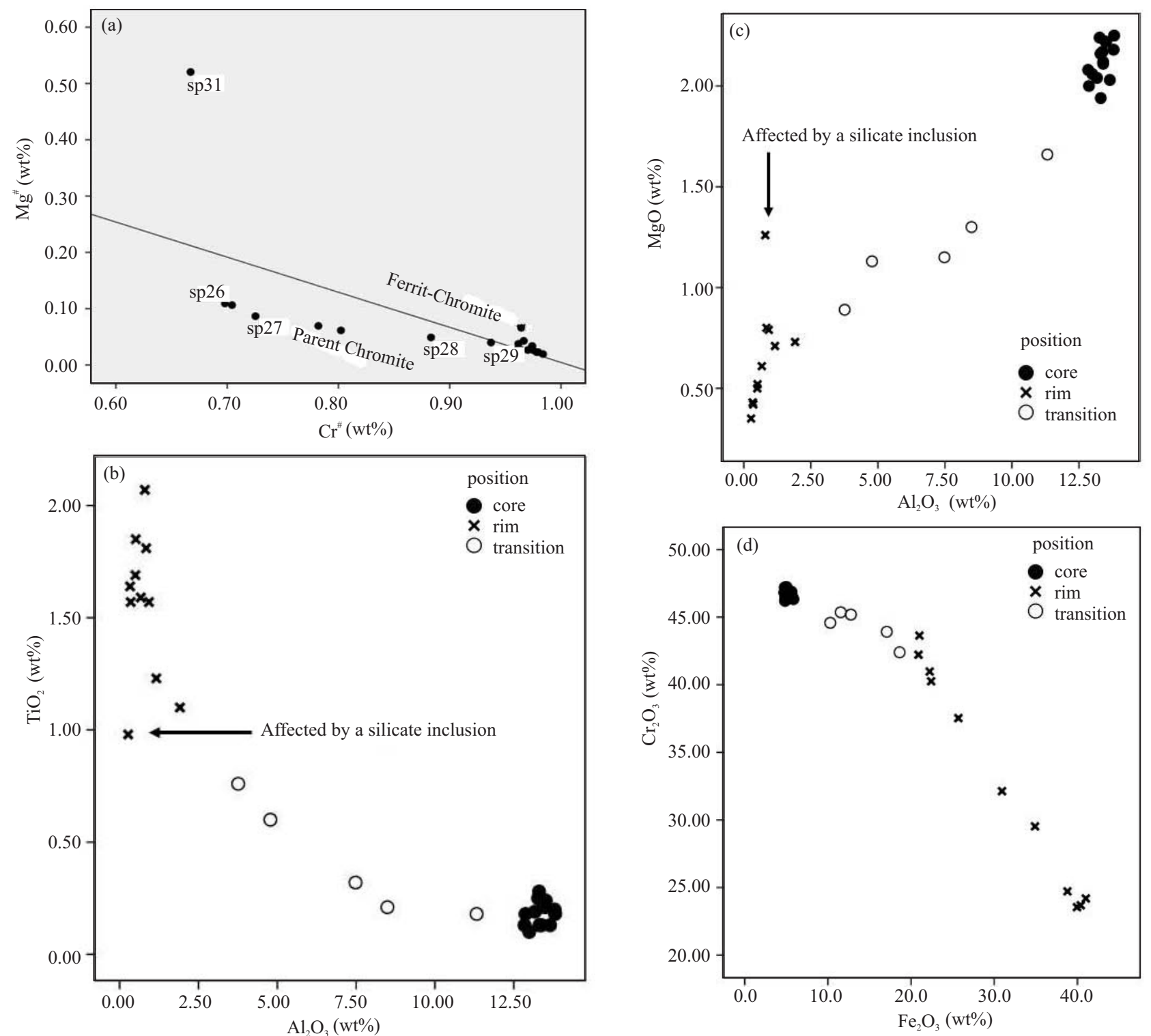

Fig. 3. (a), binary diagram of $\mathrm{Cr}^{\#} v s \mathrm{Mg}^{\#}$; (b), binary diagram of $\mathrm{TiO}_{2} v s \mathrm{Al}_{2} \mathrm{O}_{3}$; (c), binary diagram of $\mathrm{Al}_{2} \mathrm{O}_{3} v s \mathrm{MgO}$; (d), binary diagram of $\mathrm{Cr}_{2} \mathrm{O}_{3}$ vs $\mathrm{Fe}_{2} \mathrm{O}_{3}$. 


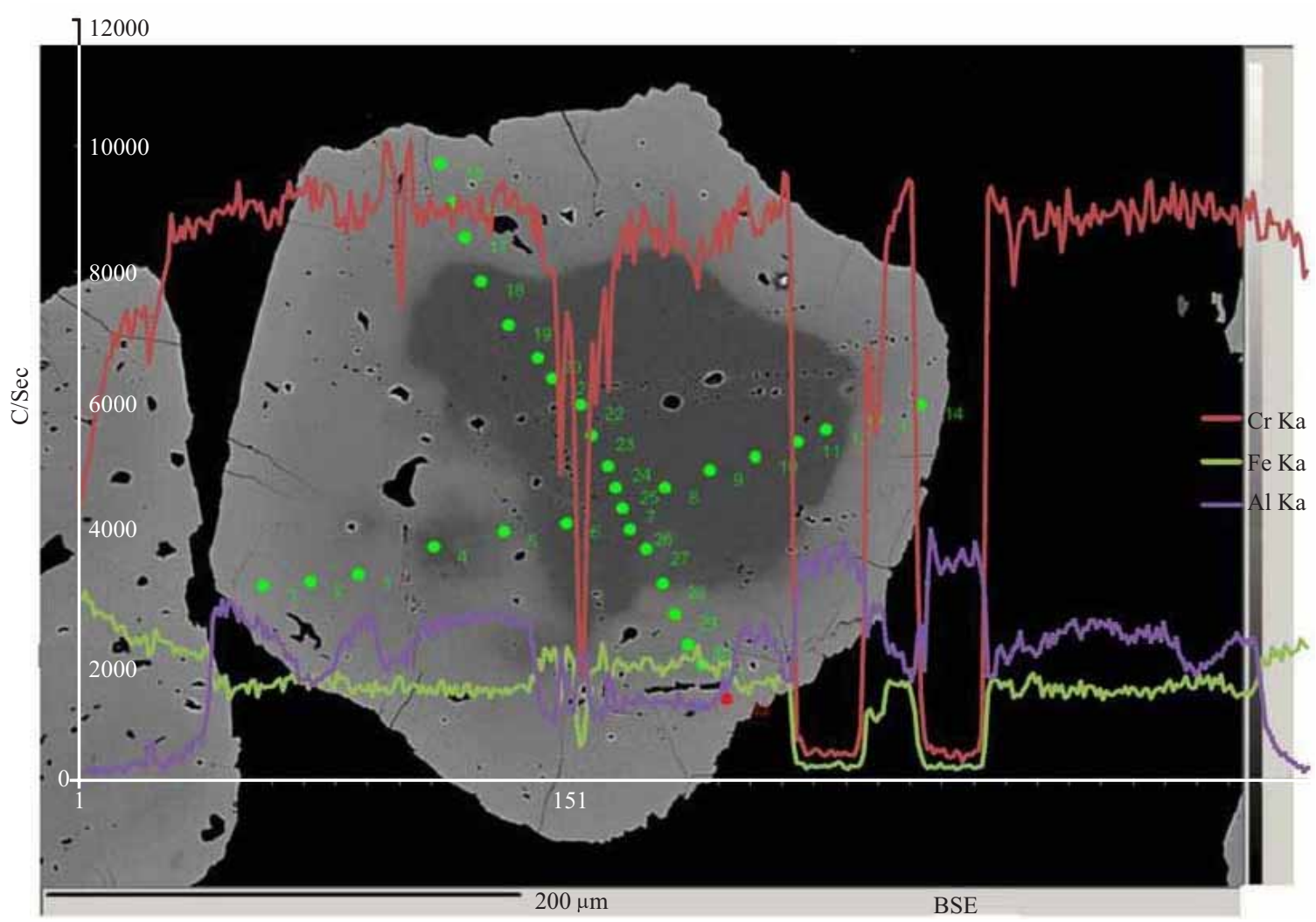

Fig. 4. X-Y profile in ferritchromite showing element variation from rim to core (note: $\mathrm{X}$ axis -distance in microns; $\mathrm{Y}$ axis - Counts/Sec).

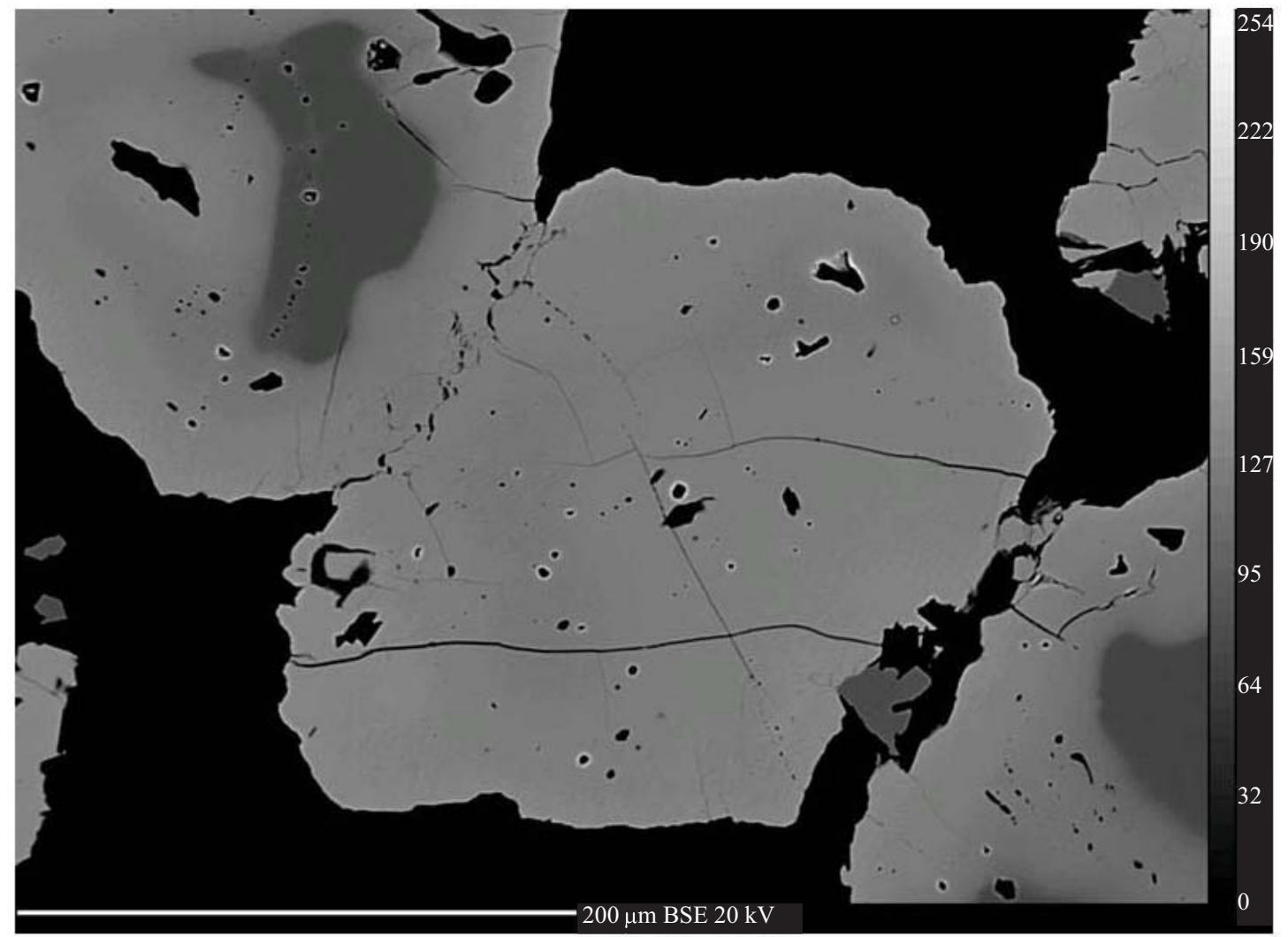

Fig. 5. Complete replacement, inner slightly darker zone of chromian magnetite. Also contain few inclusions making original chromite boundary. Chromite cores are completely disappeared (parent chromite). 
Table 1 EPMA analysis of chromite compositions

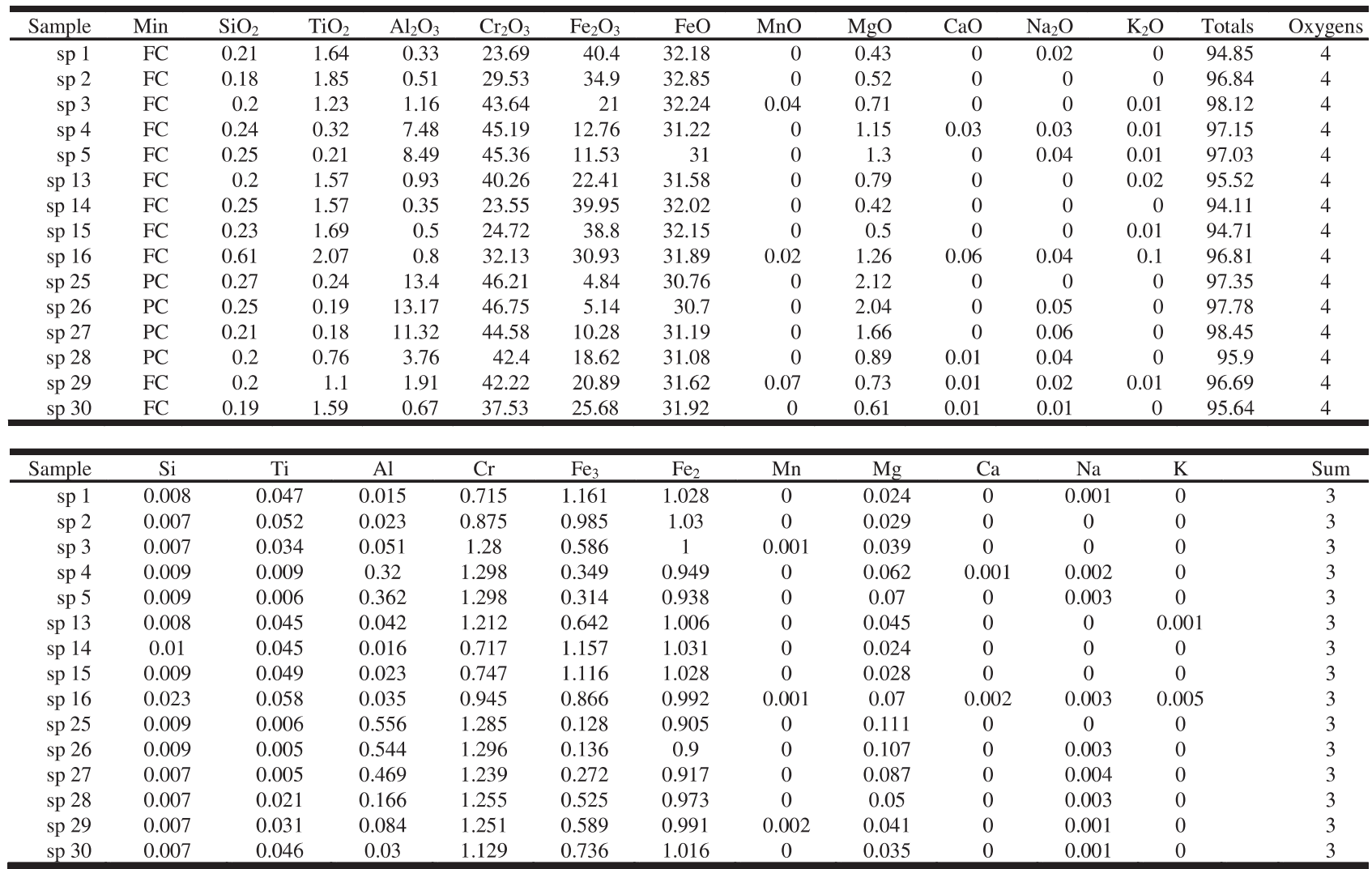

FC:ferrit chromite; PC: parent chromite or orginal chromite composition. 

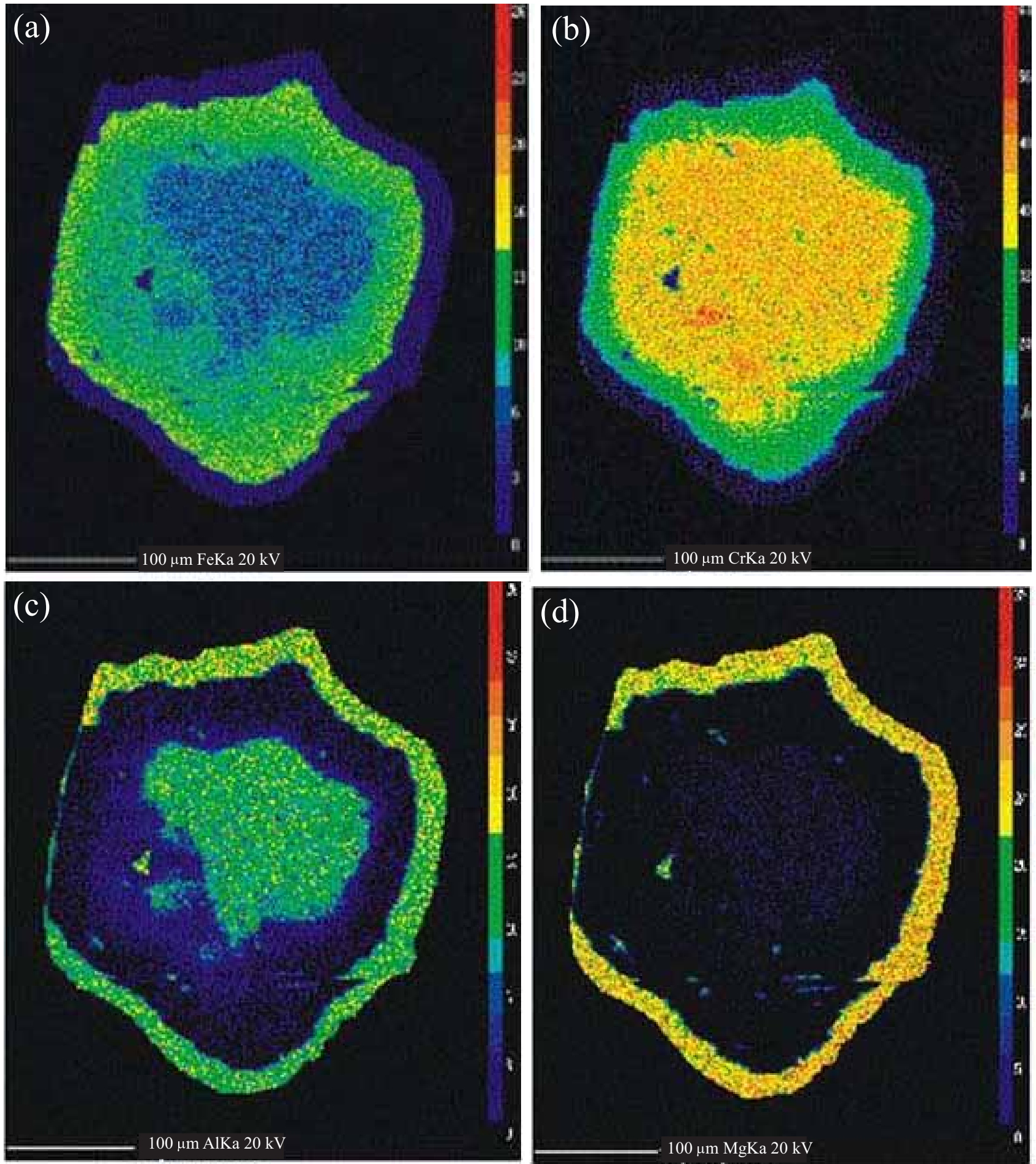

Fig. 6. (a), Element map of Fe enrichment in ferritchromite; (b), Element map of $\mathrm{Cr}$ enrichment in ferritchromite; (c), Element map of $\mathrm{Al}$ enrichment in ferritchromite; (d), Element map of $\mathrm{Mg}$ enrichment in ferritchromit. 